\title{
SANAT VE ÜTOPYA
}

\author{
Bengü BATU ERTUNG ${ }^{1}$
}

${ }^{1}$ Doç. Dr., Zonguldak Bülent Ecevit Üniversitesi, bengubatu2(at)hotmail.com,ORCID: 0000-0003-4504-252

Ertung Batu, Bengü. "Sanat ve Ütopya” idil, 64 (2019 Aralık): s. 1625-1632. doi: 10.7816/idil-08-64-02

\section{Öz}

Sanat, sınırları zorlayan yapısıyla dünyayı işleyen, genişleten ve çoğaltan, geleceğe göndermelerde bulunan bir işleve sahiptir. Ütopyacı özü ve ütopyayla ilişkisiyle bize başka dünyaların mümkün olduğunu gösterir. Tarihsel süreçte ütopyacı itki her zaman sanatla ve duyusal formlarla ilişkili bir şekilde çalışmıştır. Tür açısından melez yapıda olan ütopyalar edebi olanla siyasi olanı kaynaştırır. Sanatın ütopyacı özü 19. yüzyılın toplumsal ütopyacılarının armonik toplum tahayyüllerinde de merkezi bir konumdadır. Ütopyacı düşünürler Fransız Devriminin vaatlerini gerçekleştirmeye çabalayarak hayatın sanata dönüştüğ̈ armonik toplumlar ve ideal sistemler düşlemişlerdir. Tüm bu ütopyacı fikir ve girişimler, içinde oluştukları toplumun ihtiyaçlarına karşılık verme arzusundan doğmuş ve toplumun dönüştürülmesinde sanatın ve sanatçıların öncülük edeceğine inanmışlardır. Ütopyalarının asıl mirasçıları ise avangard sanatçılar olmuştur. Araştırmada ütopyanın bir anlatı türü olarak genel yapısı ortaya konulduktan sonra sanatın ütopyacı yönü ve ütopyayla olan ilişkisi, betimsel analiz yöntemiyle incelenmiştir. Sanat ve ütopya kavramlarının çok geniş bir kapsama alanına sahip olmaları nedeniyle araştırmada sınırlılık oluşturma gereği duyulmuştur. 19. yüzyılın Romantik ütopyalarında ve armonik toplum tasarılarında sanata ve sanatçıya merkezi bir rol veren ütopyacı düşünürler üzerinde durulmuştur. Romantik ütopyacı düşünürlerin ütopik toplum tahayyülleri, estetik tarihinde ve avangard hareketler üzerinde etkili olmuştur. Avangard sanatın bütün eleştirilerinin ve yıkıcılığının kaynağında "yeni bir toplum ve yeni bir insan" arzusu ile umudu ve ütopyacı itki vardır.

Anahtar Kelimeler: Ütopya, sanat, Saint Simon, Fourier 


\section{Giriş}

İnsanlar var olduklarından beri doğayla ve diğer insanlarla bir armoni içinde yaşayacakları bir gelecek arzulamış ve ideal toplumlar, devletler, sistemler, mitler, dinler düşlemişlerdir. Rönesansla birlikte insanın aklını kullanarak kendi geleceğini inşa edebileceğine dair bir güven atmosferi oluşmaya başlamıştır. Yeni coğrafyaların keşfi ve Rönesansın oluşturmaya başladığı yeni bilgi rejimi, insanın evreni dönüştürebileceği düşüncesini de doğurmuştur. Coğrafi keşiflerle birlikte ötekiyle karşılaşmaların çoğalması, farklı kültürlerin olabilirliğinin bilgisi, toplumsal varoluşa dair eleştirel bakışa da ivme kazandırmıştır. Skolastik düşüncenin dogmatik şekilde tanımlanmış dünyasından insan aklının merkezinde olduğu, sürekli değişism içinde bulunan, tamamlanmamış, keşfedilmeye açık ve insan aklıyla dönüşebilecek bir dünyaya geçiş süreci yaşanmıştır. Bu tamamlanmamış, değiştirilebilir ve yetkinleştirilebilir olan dünya ise insanda daha iyi bir yaşam arzusu ve umuduyla ideale dair düşlere dönüşerek ütopya için de bir alan oluşturmuştur. Ütopyaya ait özellikler insanlık tarihinde ilk olarak mitlerde ortaya çıkmış olsa da ütopya kavramını ilk kullanan ve türe adını veren kişi Thomas More'dir. 1516 yılında yazmış olduğu kitabında kurgusal bir adada bulunan ideal bir kent devletini ve siyasi sistemi tarif ederek eserine kendi türettiği bir kavram olan "Ütopya" adını vermiştir. More ütopya kavramını bir neolojizm (türenti) olarak oluşturmuştur. Neolojizmini oluştururken iki Yunanca sözcüğe başvurmuştur.

\footnotetext{
Değil/ olmayan anlamını tașıyan ve "u" sesine indirgenen "ouk" ile "yer" anlamına gelen "topos" sözcüklerine, yer bildiren "ia" sonekini ekledi. Dolayısıyla etimolojik açıdan ütopya, olumlama ve olumsuzlamayı bir paradoks olarak aynı anda içeren, aslında yer olmayan bir yer, var olmayan fantezi bir yerdir. (Claeys, 2018: 5).
}

Ütopya "Reel olmayan fakat reel olarak mümkün olan şeyin psişik öncelemesidir" (Bloch, 2013: 183). Ütopya sözcüğü var olmayan, ideal ve düşsel yerleri betimlemek amaciyla doğmuş olsa da zaman içerisinde belirli bir tür anlatıya atfen kullanılmış, bu anlatılar da ütopyacı edebiyat olarak bilinegelmiştir (Claeys, 2018: 4-5). Neolojizmler bir ihtiyaç sonucu yeni olanı adlandırmak amacıyla kullanılan kelimeler olsa da "ütopya" kavramı More'nin bu sözcüğü üretmesinden önce yazılmış metinlerden söz etmek için de kullanılmaya başlanmıştır. Hızla birçok Avrupa diline yayılmıştır. Bütün ütopyalar bir Altın Çă̆, bir Arcadia, bir komünal toplum tasavvur ederler. İlk ütopyanın MÖ. 1640 yılında Mısır'da yazılan “Kutsal Yılanlar” olduğu var sayılsa da kimi ütopya tarihçilerine göre bir tür olarak ütopyanın başlangıcı Platon'un "Devlet" kitabıdır. Ütopya edebiyatının en verimli olduğu dönemler antik ve modern çağlardır. Ortaçağda ütopya edebiyatı skolastik bilgi rejiminin şekillendirdiği atmosferde bir duraklama dönemine girmiştir. Modern ütopyalar T. More'nin bütün bu türe adını koyduğu ütopya kitabıyla başlamıştır. More'nin ütopyasını Campenella'nın “Güneş Ülkesi (1602)” ve Francis Bacon'un "Yeni Atlantis"i (1627) izler. Modern ütopyalarda antik dönem klasik örneklerden olan Platon'un "Devlet"i, “Atlantis"i ve Jambulos'un “Güneş Adaları"ndan esintiler vardır. 1789 Fransız Devrimi sonrası toplumda ütopyaların gerçekleşebileceği umudu uyanmaya başlamıştır. Devrim sonrasında toplumsal ütopyaların gerçekleşmeye en yaklaştı̆̆ zaman ise 1830 ve 1850 yılları arasındaki ütopyaların (Saint - Simon, Fourier) hayat ve sanatı kavuşturma hedeflerinin etkin olduğu devrimci dönemdir (Artun, 2011). More, "Ütopya" adlı eseriyle bir edebi geleneğin adını ve gerekli temelini oluşturmuştur. Ütopyacı edebiyat yeni bir edebi biçimdi. Bu edebi biçimin ütopyacı düşüncenin olası tezahürlerinin yalnızca bir tanesi olduğunu da kabul etmek gerekir. Bir anlatı türü olan ütopya, temel özellikleri ile ilişkili, karşıt anlamlar da içeren sözcüklerin türetilmesinde de kök olarak kullanılmıştır. Bu sözcükler arasında birer türetimsel neolojizm olarak, "eutopya, distopya, anti-ütopya, karş1ütopya, kakatopya, alotopya, eukronya, heterotopya, ekotopya ve hiperütopya" kavramları sayılabilir (Claeys, 2018: 4). Özellikle bu kavramlardan distopya, kakatopya ve anti ütopya, ütopyaların sonu söyleminin doğurduğu tartışmalarda merkezi bir yer işgal etmektedir. Anti ütopyalar edebi ütopyaların anlatı stratejilerini ve anlatısal araçlarını kullanır. Buna karşın ütopya umuda dair bir şeyse, anti ütopya ise inanmamaya dairdir. Özünde karamsardır. Ütopyayla ilişkili olan yeni sözcüklerin türetilmesiyle de ütopya kavramının anlamı ve içeriği de tarihsel süreçte keskinleşmiş ve yeni boyutlar kazanmıştır (Claeys, 2018: 4). Ütopyanın birçok disiplinle ilişkiye geçebilen melez yapısı kavram üzerinden yapılan tartışmaları da farklı zeminlerden yola çıkmaları nedeniyle karmaşıklaştırmaktadır. Felsefe, siyaset, sanat, edebiyat, bilim, mimari ve şehir planlama gibi farklı disiplinlerle ilişki içinde ve hedefleri değişken olan, kimi zaman da düşünsel olarak çatışan yazar ve araştırmacılar tarafından kullanılmaktadır. Ütopya geleceğe dair bir düzen, istikrar ve bu istikrarı sağlayan bir siyaset arayışıdır. Ama siyasetname değildir. Eleştirel yapıda metinlerdir. Eleştirinin çıkış noktası var olan, mevcut olan ve yaşanmakta olan gerçekliğin, şimdinin kendisidir. Ütopya, var olması olası olanla, henüz burada var olmayan daha iyiyi 
kurgularken şimdiyi sarsmayı amaçlar. Eleştiri, mevcut durumu değiştirmenin bir aracıdır. Tahayyül edilen, hayal edilen, öteki üzerinden var olan durumu, düzeni, toplumsal koşulları eleştirir. Şimdi, aşılması gereken durumdur. Ütopya da şimdiye direnmenin bir aracıdır. Ütopyalar örtük ve dolaylı şekilde mevcut sistemi eleştirirken başka dünyaların mümkün olduğunu göstererek yeni bir alternatif üretirler. Mevcut olan toplumsal düzenin alternatifsiz olmadığını gösterirken bu özellikleriyle yön belirleyici yapıdadırlar. Bu durum da mevcut iktidar ve bu iktidarın temellendiği ideolojiler için sorun teşkil edebilir. Çünkü alternatif üretmesiyle mevcut iktidarın da karşısında konumlanır Ütopyanın sisteme yönelik olan, ideolojilerle de ilişkili olan bu yapısı, mevcut koşullara alternatif bir dünya sunması, kavramı siyasetle de ilişkiye sokar. Daha iyi bir sistem umudu ve tahayyülü ile felsefi değerlendirmeler de içerir. Mevcut olmayan üzerine, olanakları işaret ederek düşünmeye, dönüştürmeye ve harekete geçmeye teşvik eder. Hayal edilen ideal coğrafyaları, ülkeleri, adaları, başka gezegenleri ayrıntılı kurgulamasıyla da diğer bir taraftan, uzamsal bir boyutu da daima içinde barındırır. Uzamı, "kenti ve kentin dokusunu oluşturan mimari yapıları tahayyül ettiği sistemin aksaksız ve en ideal şekilde devam edebilmesinin aracı" olarak görür. Mimari, kent ve uzam, toplumsal örgütlenmede işlevsel bir birim olarak kurgulanır. İdeal kenti, kır ve kentin uzlaşması olarak tasarlayarak ayrıntılı şekilde betimler. Tüm bu ütopyaların kurguladığı armonik hayatın aktığı ideal kentler de C.Fourier'in tasarladığı "flansterler"de somutlaşmış ve realite kazanmıştır. $\mathrm{Bu}$ yönüyle ütopyalar mimarlık ve kentle de ilişkilidir. Ütopyalar kendi içinde bağımsız bir anlatı türü olarak ortaya çıkar. İçerikleri, işlevleri ve türleri farklı olsa da daha iyi bir yaşam arzusunu, olanakları içinde barındırır. Gerçekleşebilecek her olanak, umut ile de bağlantılıdır. Umut da ütopyaların özünü oluşturmaktadır. Ütopyaların özünü oluşturan bu umut sadece pasif bir duygu değildir, gelecek olana açıktır. Bir taraftan da yön belirleyicidir. Karşımıza çok farklı türde ütopyalar çıkar. İlkelci ve nostaljik ütopyalar, bireyci ütopyalar, deniz yolculuğu ütopyaları, hicivler, anti ütopyalar, pornografik ütopyalar, feminist ütopyalar, mikro ütopyalar, anarşist ütopyalar, sosyalist ütopyalar $\mathrm{vb}$.

Tarihsel süreçte ütopyacı itki her zaman sanatla ve duyusal formlarla ilişkili bir şekilde çalışmıştır. Ütopyayla ilişki içerisinde olmayan sanatsal veya siyasi bir eylem düşünmek pek mümkün görünmemektedir. Tür açısından melez yapıda olan ütopyalar edebi olanla siyasi olanı kaynaştırırlar. "Ütopyanın şimdiyle ve reel hayatla gerçek anlamda ilişki kurduğu, somutlaştığı ve siyasetle de kimi zaman örtük, kimi zaman da açık şekilde bir eyleme dönüştüğü en önemli alan sanattır" denebilir. Estetik ve politika, böylece birbirine bağlanır. Ernst Bloch "Umut İlkesi" (2013) adlı eserinde insanı hep daha iyi olana ulaşma arzusunda olan ütopik bir varlık olarak tanımlayarak ütopya kavramını derinlemesine incelemiş̧ir. Kültürü oluşturan sanat, ideoloji ve dini ortak paydada birleştiren unsurun ütopya olduğunu belirler. Ütopya kavramının bir anlatı türü olarak sadece devlet romanlarıyla, politik sistem eleştirisiyle veya siyasetle sınırlandırılmasına karşıdır. Resimde, şiirde, mimaride mevcut olan ütopyacı unsurlar üzerinde durarak, sanat ve ütopya ilişsisini analiz eder. Bloch'a göre kültürü oluşturan ana unsur, insanın düş görme yetisidir. Bütün kültürel oluşumların temelinde insanın tasarım yeteneği vardır. İnsanın var olabilmek ve eksiklik duygusunu aşmak için düşlediğini ve geleceğe yönelik olan bu düşlerin de "gündüz düşleri”ni oluşturduğunu belirler. Bloch, gece düşünü bilinçaltıyla ilişkilendirirken, gündüz düşünü henüz bilincine varılmamış olanla ilişkilendirir. Gündüz düşleri, Freud'un geçmişi ele alan ve genellikle çocukluk dönemiyle olan bağlantısına vurgu yapan gece düşünden farklı olarak geleceğe yöneliktir. Gündüz düşleri ütopyacı itkide olduğu gibi daha iyi bir yaşam arzusundan, umuttan ve eleştirel yapısıyla daha iyiye yönelik bir arayıştan doğar. Mevcut olan durumun yarattığı hoşnutsuzluk nedeniyle bir şeylerin eksikliğinin farkına varılmıştır. Ütopyanın mevcut durum üzerinden başka daha iyi alternatiflerin olanaklı1ığını göstermesi gibi gündüz düşü de eksik olanı arar. Gündüz düşü henüz bilincine varılmamış olanın alanına aittir (Tutkal, 2016: 108). Henüz bilincine varılmamış olan ise, "gelmekte olan"dır. Bilinçlilik ve bilinç arasında konumlanmış bir kategoridir. Geleceğe göndermeler içerirken, bir taraftan da "yeni”nin doğum yeridir. Gündüz düşlerini oluşturan, henüz bilincine varılmamış şey ise sanata içkindir. Gündüz düşü, ütopik yapısıyla sanatın bir ön basamağıdır. Sanat hakikatin kaynağı olarak bizi henüz bilincine varılmamış olan hadiselere uyandırır. Bloch, sanatın bu ütopik yapısını "öngörüsel aydınlama" olarak da tanımlar (Bloch, 2013: 151). Bloch, sanatı "ütopik olanın, gündüz düşlerini eyleme geçiren, henüz var olmayanın dile getirildiği, gelecekteki gerçekliğin bir ön yansıması olarak kurgulandığı en önemli alan" olarak görür. Sanat, sınırları zorlayan yapısıyla dünyayı işleyen, genişleten ve çoğaltan geleceğe göndermede bulunan bir işleve sahiptir. Ütopyacı özü ve ütopyayla ilişkisiyle bize başka dünyaların mümkün olduğunu gösterir.

Sanat bir yönüyle aslında yazıldığ ideolojisini yansıtır. Bloch bu durumu "kültürel fazlalık" kavramıyla açıklar. Bu edebiyatın ya da sanatın 
içerisinde kendi dönemini, temsil ettiği ideolojiyi aşan bir ütopik fazlalık barındırdığı anlamına gelir (Toprak, 2011).

Bloch'a göre "ütopik fazlalık", sanatta, ideolojilerde, sembollerde, arketiplerde ve alegorilerde yerleşik düzen tarafından belirlenmiş sınırları aşan ve ihlal eden, eleştiren ve henüz olmayanı işaret eden her şeyi içerir. Sanatın barındırdığı bu ideolojiyi aşan ütopik fazlalık da başka bir dünya önerisiyle eleştirel tavrı da içinde barındırır. Bloch'un bu analizi Frankfurt Okulu düşünürlerinden Theodor W. Adorno'nun yaklaşımıyla ortak bir seyirdedir. Adorno'ya (1970) göre "Sanatın toplumsallığı, topluma karşı olmasıdır." Sanat, toplumun toplumsal antitezidir. Hegelci estetik teoriyi temel alarak tinin, kendini sanat yapıtı içinde kendine karşıt şekilde ortaya koyduğu fikrindedir. Sanat mutlak tinin cisimleşmesidir. Sanat, içinde doğmuş olduğu toplumsal gerçekliği olumsuzlayabilen ve ona eleştirel bakabilen bir yapıya sahiptir. Hakiki bütün sanat yapıtları, yapısal olarak devrimcidir. Adorno için sanattaki aşma, sanatın mevcut düzenin yanlışlı̆̆ına karşın doğru bir alternatif toplumsal düzenin mümkün olduğunu görünür kılması, resmini vermesiyle gerçekleşir. Sanatın bugünkü kurumsallaşmış topluma karşı yeni bir toplum ve var oluş önerisi bir anlamda da sanatın ütopyacı yapısına işaret eder.

19. yüzyıl büyük devrimler dönemi olup, toplumsal ütopyaların sanatın ütopyacı yönüyle yoğun bir şekilde etkileşime geçtiği zaman aralığıdır. Devrimler toplumsal çalkantıların ve bunalımların yanında ilerleme mitine dayanan daha güzel bir gelecek arzusunu ve tahayyüllerini de canlandırmıştır. Bu dönem ayrıca toplumsal ütopyaların siyasal hareketlerle birlikte somutlaşmaya en yaklaştığı dönemdir. 19. yüzyıl ütopyacı düşünürleri Fransız Devrimi'nin vaatlerini gerçekleştirmeye çabalayarak hayatın sanata dönüştüğü ütopyalar düşlemişlerdir. Tüm bu ütopyacı fikir ve girişimler, içinde oluştukları toplumun ihtiyaçlarına karşıllk verme arzusundan doğmuştu (Mcwilliam, 2011: 23). Devrimler sonrası devleti yeniden örgütleme ihtiyacı nedeniyle temel ilkeler tekrar formüle edilmeli ve yurttaşlar arasındaki ideolojik ve sosyal uçurumu daha başarılı yönetecek idari yapılar, sistemler tasarlanmalıydı (Mcwilliam, 2011: 25). İdeolojik bölünmeler, ömrünü tamamladığı düşünülen Katolikliğin geride bıraktığı manevi, metafizik boşluğu doldurma ihtiyacı, toplumsal sistemin düzgün çalışması için yeni bir inanç ortaklığının da gerekli olduğu kanısını doğurdu. Bu inanç bunalımı 19. yüzyılın ilk yarısında ortaya çıkan ütopyaları kavrayabilmemiz açısından önemlidir. 19. yüzyıl ütopyalarını temsil eden Saint Simon, Fourier, Marx, Engels, Ruskin, Robert Owen ve William Moris'in düşünceleri, yabancılaşmanın olmadığı bir armonik toplum ideali üzerine kurulmuştur. 19. yüzyılın romantik ütopyaları arasında Saint Simon'nun (17601825), Fourier'in (1772-1837), William Moris'in (1834-1896) ve takipçilerinin armonik toplum tasarıları, sanata ve sanatçıya atfettikleri önemli rollerle avangard hareketlerin rehberi olmaları açısından önemlidir. Bu ütopya tasarıları estetiğin bir önceki yüzyılda yalnızca güzelliğe ve duygulanıma dair ayrı bir araştırma alanı olarak değil, politik etki yaratacak ve toplumu dönüştürecek bir duygu analizi olarak da doğuşunun izlerini yansıtırlar (Mcwilliam, 2011: 329). Toplumsal sınıfların ortadan kalktığı, mülkiyetin, yabancılaşmanın sona erdiği armoni içinde yaşayan toplumu ve geleceği ise, sanat vaat eder. Toplumun dönüştürülmesine sanatın ve sanatçının öncülük edeceğine inanırlar. Sanatın toplumsal iş bölümü içerisindeki sınırları da yeniden tanımlanır. Sanatçının avangard, öncü kimliği böyle bir atmosfer içerisinde kurulur. Avangard sanatın bütün eleştirilerinin ve yıkıcılığının kaynă̆ında yeni bir toplum, yeni bir insan arzusu ve umudu, ütopyacı itki vardır.

"Bu arzunun yükseldiği özellikle buhran dönemlerinde sanatın göreve çağırılması, ütopyanın öncelikli bir biçim sorunu olduğunun da kanıtıdır. Geleceğin duyumsal maddi formlarla araştırılması gerekir”(https://www.eskop.com/skopbulten/gercekci-utopyalar).

Sanatın, siyasetin ve estetiğin politikasını kuran, bu gelecek vaadidir. "Avangard" kavramını yeni toplum tasarısında sanatçılara yüklenen misyonu belirtmek amacıyla kullanan ilk kişi Saint Simon'dur. Bir askerlik terimi olan avangard "bir ordunun, birliğin öncü kolu" anlamına gelmektedir. 1830'lardan sonra ütopyalar döneminde siyaset diline girerek köklü dönüşümlerin bayraktarı anlamında kullanılmaya başlamıştır. Yeni toplumsal tasarının gerçekleşmesinde sanata verilen öncü rolü ifade eder (Bürger, 2004: 10-11). S. Simon eserlerinde Hristiyanlığa eleştiriler getirerek topluma rahipler ve dinin kılavuzluk ettiği dönemin kapandığını, topluma filozoflar, bilginler ve sanatçıların kılavuzluk edeceği, sanat ve sanayinin kaynaştığı bir dönemin başlaması gerektiği uyarısında bulunur (Meriç, 1996: 55). Tahayyül ettiği sistem Fransız sosyalist düşüncesinin oluşumunda merkezi rol oynar. Sosyalist ütopyalar Hristiyanlığın miadını doldurduğuna inanıyorlardı. Bilim, endüstri ve güzel sanatları toplumu daha iyiye götürecek yeni kutsallar olarak konumlandırırlar. Simon'a göre içinde bulunulan bu buhran döneminde hem dünyayı açıklayacak bir felsefeye, hem bir ahlak düzenine, hem bir heyecan kaynağına, hem de insanları kaynaştıracak bir düşünce mayasına ihtiyaç vardı (Meriç, 1996: 44). İnsanları heyecanlandıracak ve kaynaştıracak 
maya ise sanat ve sanatçılardı. İdeal toplum tasarısında duygulara da yer verilmeliydi. Sanat ve dinle ilişkilendirdiği duyguları, insanı harekete geçiren evrensel güç olarak görmüştür. İlk metinlerinde sosyal değişimin itici gücü olarak akla ve pozitivist epistemolojinin geliştirilmesine öncelik verse de süreç içerisinde ütopyacı toplum tasarısında sanatın etkileme gücünü merkezi bir konuma getirir. Bir taraftan da bilim ve tekniğin ancak sanatın şiirsel boyutlarıyla birleştiği zaman, çoğunluğun özlemine cevap verebileceği inancını geliştirir. Simon'a göre ilerlemenin ve daha iyi bir dünya yaratılmasının kaynağında insan emeği vardır. Tasarladığ sistemde en temel amacı, "sosyal çatışmalar olmadan, barış içerisinde gelişme”nin yollarını bulmaktır. Sanatın, kamuoyuna seslenerek, tahayyül ettiği ütopyacı sistemin, amaçlarını gerçekleştirmesini kolaylaştıracağını düşünmektedir. Sanatçı, halkın duygularına seslenerek çoğunluğun desteğini kazanmayı sağlayacak bir propagandacı olarak algılanmaktadır. Sanatın ve sanatçının temel işlevi anlamın ve ideolojilerin aktarılmasıdır. Sanatçı, politik meselelerin gerektirdiği işleri yerine getiren bir propagandacı kimliğine bürünür. Yönetenlerin planlarındaki anlaşılması zor rasyonalizmi sanat diline çevirerek ve halkı coşturarak, fikirlerin toplum tarafından hızla benimsenmesini sağlayacaktır. Böylelikle sınıf çatışması görünürde yok olacak ve direniş engellenecektir (Mcwilliam, 2011: 71). Duyguyu kullanarak organik toplum arzusunu gerçekleştirmeye çalışır. Tahayyül ettiği sistemde faydacı estetiği savunur. Duyguya giderek daha fazla önem verdiği için sanatçıyı yönetici elitine (savant), devleti de yönetme projesine dâhil eder. Simon'un tasarısı, sanatçıları yönetici elitin belirlediği politik ihtiyaçlara uyumlu bir işleve ve konuma getirmesi açısından eleştirilmiştir. Sanatçının bireysel özgürlüğü ve yaratıcılığının engellendiği düşünülmüştür. Hareketin bireycilik karşıtlığı da sanatçılar arasındaki çekiciliğini sınırlayan en önemli faktör olmuştur.

19. yüzyılın ütopyalarından Charles Fourier'in felsefesi de Romantiklerle başlayan sanatın özerkleşme hareketini siyasallaştıran modernist ve avangard hareketlerin rehberi olmuştur. Simon öldükten sonra arkasından birçok Simonist ütopya cemaatleri kurulur. Simon'un takipçilerinin etkilerini yitirmeye başladığı dönemde Fourier'in ütopik cemaati ortaya çıkar. Fourier insan tabiatındaki ihtirasları ve arzuları çözümlemekle işe başlar. İnsanı sadece mantık varlığı olarak ele alan gelenekten kopar. Ütopyasında insan hayatının estetikleştirilmesi üzerinde durur. Ütopik cemaatlerinin yerleştiği kentleri de "flanster" olarak adlandırır. Fourier'in ideal cemaatleri, komünleri flansterlerdir (phalanster). Flansterler hayal gücünün, tukuların, cinsel özgürlügün ve arzuların yönettiği ütopik, armonik evrenlerdir. Ütopyasında sanat, siyaset, etik, eleştiri ve bilim, birbirine kaynamış pratiklerdir. İnsanlar arası toplumsal armoniyle estetik armoniyi özdeşleştirir. Sanat ve hayatı özdeşleştirerek insanın estetik sistem içerisinde her tür yeteneğini gerçekleştirebileceği armonik toplumlar tahayyül eder. Fourier ve takipçilerinin yaklaşımları ABD’nin feminist ve işçi hareketleri üzerinde uzun bir zaman etkili olmuştur. Fourier'in hayal gücü, tutkular ve arzuları merkeze alan, romantik ütopyası Dada'dan, Sürrealizme, Sitüasyonizme uzanan avangard hareketleri etkilemiştir. Bu avangard hareketlerin merkezinde de 'phantasma' bulunur.

İngiliz romantiklerinden William Moris de "hayatın estetikleştirilerek armonik bir toplum kurulacağı"na inanır. 1890 yılında "Hiçbir Yerden Haberler" (News from Nowhere) adlı eserini yayınlar. Morris, tarihi, insanın büyüme ve gelişme süreci olarak görüyordu. Sonunda insanlık bir olgunluk haline erişecek ve ideal toplum da bunun içinde belirecektir (Claeys, 2018: 19). Ütopyasında devletin ortadan kalktığı, insanların sadece haz almak için çalıştığı, ürettiği komünal yaratıcılık toplumunu betimler. Ütopyasında emek, sınıf ve ürün kavramlarını yeniden tanımlar. Emeğin yabancılaşmadan kurtarılmasına yönelik bir yaklaşım içerisindedir. Sanayiye karşı sanat ve zanaatı savunur ve çalışmalarıyla Art and Craft hareketine öncülük eder. Saint Simon ve Fourier ütopik toplum tasarıları, Marx ve Engels tarafından birçok eleştiri almıştır. Engels "Bilimsel ve Ütopik Sosyalizm" kitabında Saint Simon ve Fourier'i reddetse de, Marx ve Engels'in komünizmi de nihayetinde bir şairler tolumu öngörür. Sınıfların, iş bölümünün ve uzmanlaşan sanatın son bulacağı bir ütopya vaat eder. Sanatın hayat olduğu bir toplum önerisinde bulunurlar. İdeal toplum bir tür "topyekûn sanat eseri, bir gesamskunstwerk (toyekun sanat eseri)" gibi tahayyül edilir.

19. yüzyıl ütopyalarının asıl mirasçıları avangard sanatçılardır. Ütopyalarının temelini oluşturan sanat ve sanayi diyalektiği, estetik tarihinde 20. yüzyıl avangardının da akıl (logos) ve hayal gücüne (phansama) öncelik veren yaklaşımlar olarak ikiye bölünmesine neden olmuştur. Özellikle Saint Simon ve Fourier'in armonik toplum tasarıları avangard hareketlerde somutlaşmıştır. Avangard hareketler Fütürizm, Dada, De Stijl, Bauhaus, Sürrealizm ve Rus avangardları Süprematizm ve Konstrüktivizm, sanatın değeri ve toplumsal yaşamdaki yeri üzerine teoride ve pratikte üretim yaparken ütopyalar için imgesel sı̆̆ınaklar inşa etmişlerdir (https://eskop.com/skopbulten/gerçekçi-utopyalar/3517). Saint Simoncu ütopya, Konstrüktivizm, De Stijl, Bauhaus gibi 
sanat, sanayi diyalektiğine dayanan merkezinde logos olan avangardların habercisidir. Sanatçıı bilim adamı ve mühendisle özdeşleştirmiştir. Simon sanatçıyı armonik toplumunda yönetici konumuna getirirken, ideal toplumunda sanatı rasyonelleştirerek araçsallaştırmıştır. Simon'un bu yaklaşımı 1. Dünya Savaşı sonrası Rus avangardlarıyla ortak bir tavır izler. Örgütlenme biçimleri batıdaki avangard hareketlerden farklı olsa da Rus Avangardları'nın doğuşu, tarihsel olarak batıyla eşzamanlıdır. Estetik yönelimleri de benzerdir. Rusya'da avangard, düşünsel ve siyasal birliktelikler kuran koloniler, kolektifler içinde örgütlenmiştir. Ütopisttirler, devrimci bir dönüşüm sayesinde insanların armonik topluma kavuşacağını tahayyül ederler. Toplantılarında da bu amaç doğrultusunda geçici sergiler kurarak, konserler, tiyatro ve şiir okuma etkinlikleri düzenleyerek sanatı ütopik toplum tasarılarında itici güç olarak kullanırlar. "Gesamtkunstwerk" idealine bağlıdırlar (Artun, 2015: 40). Devrimle çağdaş olan Rus avangard sanatçıları arasında ütopya dilinin kaynağ geometri ve aritmetiktir. Maleviç’in belirttiği gibi geometri ve matematik kusursuz ama erişilmez bir toplumsal düzeni dile getiren ütopyanın imgeleriyle birleşmiştir. Armoni de sık sık Suprematist ve Konstrüktivist tarzda üretimlerde geometrik formlarla ifade edilmiştir. Suprematizm formlar metafiziği, kozmik bir armoni arayışıyla; Konstrüktivizm ise sanatın üretimle hayatın içinde olduğunu vurgulayarak ütopyalarla ilişkilendirebilir. "Konstrüktivistlerin saiklerinden bir diğeri de Marx'ın "Alman İdeolojisi” eserinde değindiği, iş bölümünün sona ermesi sayesinde sanatçı ve emekçi ayrımının ortadan kalktığı ütopyalar"dır (Artun, 2015: 90). Bauhaus'un Rus avangardıyla ilişkisi de estetik bir ittifak olmaktan çok, siyasaldır. Almanya'da açılan Bauhaus Okulu "geleceği kurmak" ideali ile estetik amaçlardan çok toplumsal amaçlara yönelmiş bir yapı olarak kurulmuştur. 1920'lerin Almanya'sında Bauhaus felsefesi -özellikle de dönemin sanatçı birliklerinden İşçi Sanat Konseyiyle bağlantısı olanlar- "küçük bir kesime lüks üretmek yerine geniş bir kesime kullanışlı yaşam alanları yaratabilmek düşüncesi” üzerine kurulmuştur (Antmen 2010: 104). Bauhaus yaklaşımı ile Rus avangardının "formların yeni bir dünya, sınıfsız bir toplum, şiirsel bir hayat yaratabileceği umudu" noktasında ütopyacı tavırları aynıdır (Artun, 2015: 179). Konstrüktivistler ve Bauhaus sanatçıları yeni bir dünyanın kurulmasını gereklilik olarak görmüşler; giderek tasarıma yöneldikleri bir süreç içerisinde sanatı toplumsal bir zeminde anlam ifade etmesi gereken bir olgu olarak düşünmüşlerdir. Her şeyden önce işlevselliğe önem vermişlerdir.

\section{Sonuç}

19.yüzyılın devrimci siyasi hareketleri ve avangard sanatçıların, "evrenin yenilenmesi, özgür ve armonik bir toplum tasarısı" konusunda aynı siyasal ütopyayı, zemini paylaştıkları görülür. Dünyaya manifestolarla, eylemlerle, şiirle, tiyatroyla, performanslarla ve yapıtlarıyla seslenerek ve davalarını duyurarak, enternasyonal hareketlere dönüşmüşlerdir. Tüm bu “ütopya - sanat ilişkisi” üzerinden örneklendirilen, ele alınan küçük bir kesit; "ütopyanın sistem olarak realite kazanamadığı noktalarda sanat yoluyla somutlaştığının ve toplumsal düşünsel dönüşümler yarattığının” kanıtıdır. Sanat ve ütopya toplumsal varoluşumuz açısından doğa yasası gibi bir zorunluluktur. İçinde bulunduğumuz dünyadan daha iyi bir dünya umudunu canlı tutmaları açısından önemlidirler. Ütopya tarihsel süreci okumanın ve yorumlamanın kaynaklarını ve olanaklarını da zenginleştirmektedir. Arzulanmış olana, "umuda bakarak bir dönemi okuyabilmenin ve farklı boyutlardan kavrayabilmenin" olanağını açar. Sanatın, tarihin, eleştirinin ve ütopyaların sonunun ilan edildiği bu çağda umuda her zamankinden daha çok ihtiyaç vardır. Ütopyanın ölümünü ilan etmek, "insanın hayal etme yetisinin ve alternatifleri düşünebilme kapasitesinin yitimi”ni de kabul etmektir. Ütopya, bize dayatılana, karşı bir dünyanın mümkün olduğunu gösterirken umut etmemizi ve eleştiri kültürünün de oluşmasını sağlar. Bunu görsel, işitsel ve edebi olarak hafızalarımıza kazımak ve somutlaştırmak da kuşkusuz sanatın sorumluluğudur.

\section{Kaynaklar}

Adorno, T. W. Aesthetic Theory. Ed. G.Adorno ve Rolf Tidemann. Minneapolis: University of Minnesota Press, 1970.

Antmen, Ahu. 20. Yüzyıl Batı Sanatında Akımlar. İstanbul: Sel Yayıncılık, 2010.

Artun, Ali. Sanatın İktidarı, 1917 Devrimi Avangard Sanat ve Müzecilik. İstanbul: İletişim Yayınları, 2015.

Artun, Ali. "Sanat Hayali, Yönetim Disiplini ve Sanat Yönetimi: Avangard ve Taylorizm” 6 Aralık 2019.

http:www.aliartun.com/yazilar/sanat-hayali-yonetim-disiplini-ve-sanat-yonetimi-avangard-ve-taylorizm/

Artun, Ali. "Mutluluk Hayalleri” (26 Ocak 2011) 6 Aralık 2019. https://www.e-skop.com/skopbulten/mutlulukhayalleri/460 
Artun, Ali. der. "Manifesto Avangard Sanat ve Eleştirel Düşünce”(2010) $10 \quad$ Ekim 2019 http://www.aliartun.com/yazilar/manifesto-avangard-sanat-ve-elestirel-dusunce/

Bloch, Ernst. Umut İlkesi Cilt 1. Çev. Tanıl Bora. İstanbul: İletişim Yayınları, 2013.

Bürger, Peter. Avangard Kuramı. İstanbul: İletişim Yayınları, 2004.

Claeys, Gregory. (Haz.) Ütopya Edebiyatı. Çev. Zeynep Demirsü ve Damla Göl İstanbul: Türkiye İş Bankası Kültür Yayınları, 2018.

e-skop “Gerçekçi Ütopyalar” (18 Eylül 2017) 8 Ekim 2019. https://e-skop.com/skopbulten/gerçekçi-utopyalar/3517

Löwy, Michael. "Ernst Bloch ve Sürrealizm” (21 Ekim 2014) 7 Aralı $2019 . \quad$ https://www.eskop.com/skopbulten/surrealizm-1924-2014-ernst-bloch-ve-surrealizm/2164

McWilliam, Neil. Sanat Ütopya, Mutluluk Hayalleri Sosyal Sanat ve Fransız Solu. İstanbul: İletişim Yayınları, 2011.

Meriç1, Cemal. Saint Simon, İlk Sosyolog İlk Sosyalist. İstanbul: İletişim Yayınları, 1996.

Neslihanoğlu, E. Funda. 'Kendini Gerçekleştirme Ütopyası ya da Ütopyanın Gerçeklenmesi'. Felsefe Tartışmaları 27. Kitap (2000): 143-149.

Toprak, Metin. "Ernst Bloch’un Felsefesinde İdeoloji, ütopya sanat ve Din İlişkisi” (2011) 8 Ekim 2019. Academia.edu/5588916/Ernst_Bloch_un_Felsefesinde_İdeoloji_Ütopya_Sanat_ve_Din_Arasındaki_İlişkisi.

Tutkal, Serhat. Ernst Bloch Ütopyacılık ve Kurtuluşu Teorileri. Yayımlanmamış Yüksek Lisans Tezi. Ankara: Ankara Üniversitesi, 2016. 


\title{
UTOPIA AND ART
}

\author{
Bengü BATU ERTUNG
}

\begin{abstract}
With its structure that pushes limits, art has the function of processing, extending and reproducing the world and referencing the future. It shows us that other worlds are possible with its utopian essence and its relationship with utopia. Throughout the historical process, the utopian urge has always worked in relation to sensual forms. Utopias that have a hybrid structure in terms of genre fuse the literary with the political. The utopian essence of art is also the centerpiece in the harmonious society fantasies of the 19th century societal utopians. Utopian thinkers strived to realize the promises of the French revolution and imagined harmonious societies, ideal systems where life transforms into art. All these utopian ideas and attempts stemmed from the desire to meet the needs of the society in which they were created. These thinkers believed that art and artists will lead the transformation of society. The actual inheritors of their utopias turned out to be avant-garde artists. In the study, first the general structure of utopia as a narrative genre is presented, and then the utopian aspect of art and its relationship with utopia are examined with the descriptive analysis method. As the art and utopia concepts have a very wide scope, it was deemed necessary to set boundaries in the study, and the utopian thinkers that gave a central role to art and artist in their harmonious society fantasies in the romantic utopias of the 19th century were considered. The utopian society fantasies of romantic utopian thinkers influenced the aesthetic history and the avant-garde movements. All the criticisms and destructiveness of avant-garde art stem from the desire and hope for a new society and new humanity and the utopian urge.
\end{abstract}

Keywords: Utopia, art, Saint Simon, Fourier 